\title{
HUBUNGAN PEKERJAAN DAN KONDISI SOSIAL BUDAYA DENGAN STATUS GIZI MASYARAKAT DI DESA LAWALLU KECAMATAN SOPPENG RIAJA KABUPATEN BARRU
}

\section{The Relationship between work and Socio-Cultural Conditions with the Nutritional Status of the Community in the Village of Lawallu Sub-District, Soppeng RiajaRegency, Barru}

\author{
Nursamsi, Haniarti, Abidin \\ (Program Studi Kesehatan Masyarakat Fakultas Ilmu Kesehatan Universitas Muhammadiyah \\ Parepare) \\ nursyamsi11296@gmail.com (085340877190)
}

\begin{abstract}
ABSTRAK
Masalah gizi masyarakat di Desa Lawallu Kecamatan Soppeng Riaja Kabupaten Barru, bukan menyangkut aspek kesehatan saja, melainkan aspek kondisi sosial budaya, dan sebagainya. Kasus gizi/status gizi masyarakat akhir-akhir ini di Indonesia telah menyadarkan pemegang kebijakan untuk melihat lebih jelas bahwa orang dewasa sebagian kekurangan gizi. Penyebab kurang gizi, pertama makanan yang kurang dan penyakit infeksi yang di derita masyarakat, ketahanan pangan di keluarga, pola pengasuhan anak, pelayanan kesehatan dan kesehatan lingkungan, dan kondisi sosial budaya.Tujuan penelitian ini adalah untuk mengetahui adakah hubungan pekerjaan dan kondisi sosial budaya dengan status gizi masyarakat. Jenis penelitian survey analitik dengan pendekatan cross sectional study. Populasi dalam penelitian adalah semua masyarakat yang berumur 21-65 tahun yang berjumlah 1190 orang di Desa Lawallu dan sampel 92 orang. Data dianalisis secara univariat dan bivariat menggunakan uji statistic Chi Square melaliu SPSS Versi 24.Hasil penelitian menunjukkan bahwa tidak ada hubungan antara pekerjaaan terhadap status gizi masyarakat di Desa Lawallu Kecamatan Soppeng Riaja Kabupaten Barru berdasarkan hasil Uji Chi Square, yang di peroleh dengan taraf signifikan (0.089) $>a(0.05)$, sedangkan kondisi sosial budaya terhadap status gizi masyarakat di Desa Lawallu Kecamatan Soppeng Riaja Kabupaten Barru di peroleh dengan taraf Signifikan (0.479) > $a(0.05)$, maka H0 di tolak. Disarankan perlunya pendidikan gizi kepada masyarakat sebagai pengolahan menu keluarga untuk meningkatkan status gizi masyarakat.
\end{abstract}

Kata kunci : Hubungan pekerjaaan, kondisi sosial budaya dengan status gizi masyarakat

Community Nutrition issues in Lawallu Village, Soppeng Riaja District, Barru Regency, do not concern health aspects, but aspects of socio-cultural conditions, etc. Nutritional cases / the final nutritional status of the community in Indonesia have made policy holders aware of more obvious evidence that adults are partly malnourished. Causes of malnutrition, first lack of food and community-afflicted infectious diseases in the family, patterns of childbirth, health and health services around the home, third occupational relationships, knowledge trust, and socio-cultural conditions. The purpose of this study was to find out whether there were work relations and sociocultural conditions with the nutritional status of the community. Type of analytic survey research with cross-sectional study approach. Population in the study were all people aged 21-65 years, amounting to 1190 people in Lawallu Village and a sample of 92 people. Data were analyzed by uni variate and 
bi variate using Chi Square statistical tests through SPSS Version 24. The results showed that there was no relationship between work and status Community nutrition in Lawallu Village, Soppeng Riaja District, Barru Regency was based on the results of the Chi Square Test, which was obtained at a significant level (0.089)> a (0.05), while the socio-cultural condition of community nutrition in Lawallu Village, Soppeng Riaja District, Barru Regency was obtained by significant level (0.479)> a (0.05), then $\mathrm{HO}$ is rejected. It is recomemended that the need for nutrition education to the society as aprocessing of the family menu to improve the nutritional status of the society.

Keywords: Job relations, socio-cultural conditions with community nutritional status 


\section{PENDAHULUAN}

Peningkatan derajat kesehatan masyarakat sangat diperlukan dalam mengisi pembangunan yang dilaksanakan oleh bangsa Indonesia. Salah satunya upaya peningkatan derajat kesehatan adalah perbaikan gizi masyarakat. Gizi yang seimbang dapat meningkatkan ketahanan tubuh, dapat meningkatkan kecerdasan dan menjadikan pertumbuhan yang normal. ${ }^{1}$

Terdapat beberapa faktor yang dapat mempengaruhi status gizi diantaranya adalah faktor langsung: konsumsi makanan dan penyakit infeksi. Serta faktor tidak langsung antara lain tingkat pendapatan, pengetahuan tentang gizi dan pendidikan. Berbagai faktor sosial ekonomi akan mempengaruhi pertumbuhan anak. Faktor sosial ekonomi tersebut antara lain: pendapatan keluarga, pekerjaaan, pendidikan dan pemilikan kekayaan atau fasilitas. $^{2}$

Kebiasaan masyarakat sebagai nelayan dalam kesehariannya bekerja mencari ikan di laut dan sebagai petambak merupakan factor kebiasaan yang merupakan budaya yang ditemui dalam observasi dilapangan yaitu ikan yang mahal di pasaran menjadi komoditi penghasilan sementara, yang harga murah atau tidak terjual untuk dikonsumsi keluarga, begitu juga dengan hasil panen lainnya seperti buah-buahan. Bahan makan yang mengandung serat dan vitamin seperti sayuran bukanlah yang utama atau penting. Konsumsi protein hewani yaitu daging hanya ditemui pada saat hari-hari penting seperti acara pesta, maulid nabi dan lebaran, dan itupun jarang dialami oleh anak balita. Pembelian telur ayam yang berlebihan untuk anak-anak masih dianggap dapat menimbulkan bisul dan begitu juga dengan anggapan banyak makan ikan akan cacingan, kebiasaan pemberian pisang untuk bayi. $^{3}$

Budaya sebagai suatu perkembangan dari kata majemuk budi daya, yang berarti daya dari budi, karena itu harus dibedakan antara budaya dengan kebudayaan. Budaya adalah daya dari budi yang berupa cipta, karsa dan rasa, dan kebudayaan adalah hasil dari cipta, karsa dan rasa tersebut. Hal-hal ini yang perlu diperhatikan dalam pengaruh budaya antara lain sikap terhadap makanan, penyebab penyakit, kelahiran anak dan produksi pangan, kebiasaan makan yang baik adalah yang dapat menjamin tercukupinya kebutuhan gizi, sedangkan kebiasaan makan yang buruk yaitu kebiasaan yang dapat menghambat terpenuhinya kecukupan gizi. Kebiasaan makan yang salah dan berlangsung dalam jangka waktu yang cukup lama dan berimplikasi pada rendahnya status gizi masyarakat . ${ }^{4}$

Status gizi di Negara-negara yang sedang berkembang ini termasuk di Indonesia masih sangat memperihatinkan. Terutama di Desa Lawallu Kecamatan Soppeng Riaja Kabupaten Barru. Tradisi kuliner suatu daerah berbeda- 
beda dengan tradisi kuliner daerah lain.

Dalam suatu masyarakat menghidangkan makanan tergantung pada pola makan keluarga yang berasal dari kelompok etnis dan keagamaan yang sama dan menempati posisi sosial ekonomi yang sama, seperti halnya pada tradisi makan dimana dalam suatu rumah masih berlaku kebiasaan mendahulukan kepala keluarga untuk menyantap makanan kemudian disusul oleh anggota keluarga lainnya. Kebiasaan makan juga berhubungan dengan jaringan sosial anggota kelompok dalam menghidangkan jenis makanan dalam keluarga. Kebiasaan menghidangkan makanan juga dipengaruhi oleh pendidikan formal orang yang menyiapkan makanan. Masyarakat di Desa Lawallu memiliki latar belakang budaya, pekerjaan, pendidikan yang berbeda. Suku bangsa atau etnis penduduk memiliki latar belakang budaya, pekerjaan, pendidikan yang berbeda. ${ }^{4}$

Tradisi kuliner suatu daerah berbeda-beda dengan tradisi kuliner daerah lain. Dalam suatu masyarakat menghidangkan makanan tergantung pada pola makan kelurarga yang berasal dari kelompok etnis dan keagamaan yang sama dan menempati posisi sosial ekonomi yang sama, seperti halnya pada tradisi makan dimana dalam suatu rumah masih berlaku kebiasaan mendahulukan kepala keluarga untuk menyantao makanan kemudian disusul oleh anggota keluarga lainnya. Kebiasaan makan juga berhubungan dengan jaringan sosial anggota kelompok dalam menghidangkan jenis makanan dalam keluarga. Kebiasaan menghidangkan makanan juga di pengaruhi oleh pendidikan formal yang menyiapkan makanan.

Bila hal tersebut di biarkan dan tidak ditanggulangi dengan cepat, maka perkembangan menjadi terhambat, karena masalah gizi memiliki dimensi yang luas, tidak hanya merupakan masalah kesehatan tetapi juga masalah sosial, ekonomi, budaya, pola asuh dan lingkungan, yang menyebabkan timbulnya masalah gizi antara lain adalah kemiskinan/daya beli, pengetahuan gizi, jumlah anggota rumah tangga, kebiasaan makan, hubungan antar laju kelahiran yang tinggi dan kurang gizi, sangat nyata terutama pada rumah tangga yang sangat menentukan kualitas makanan yang dikonsumsi, dimana faktor yang sangat menentukan kualitas makanan adalah tingkat pendapatan meningkatnya pengeluaran. Status gizi ini menjadi penting karena merupakan salah satu factor risiko terjadinya. ${ }^{5}$

Data kantor desa menyebutkan $40 \%$ penduduk pria di wilayah pemerintahannya berprofesi sebagai nelayan. Jika musim kemarau tiba, laki-laki di desa itu terpaksa turun ke laut untuk menyambung hidup kelurga mereka. Dimana masyarakat di daerah itu masih ada tradisi di kalangan orang tua yang merasa malu, jika anak gadis yang berusia diatas 20 tahun belum menikah, sehingga hal inilah yang perlu di tegaskan dengan memberikan pemahaman kepada 
orang tua, agar anak perempuan atau gadis mereka bisa melanjutakn pendidikan ke jenjang lebih tinggi.

Berdasarkan data jumlah penduduk pada tahun 2017 didapat 1190 orang yang terdiri dari laki-laki 585 orang dan 605 orang penduduk perempuan dengan berbagai jenis pekerjaan diantaranya PNS, Nelayan, Petani, Pedagang, Wiraswasta, Buruh, Tukang Ojek. Untuk itu, penulis tertarik untuk mengadakan penelitian mengenai hubungan pekerjaan dan kondisi sosial budaya dengan status gizi masyarakat di Desa Lawallu Kecamatan Soppeng Riaja Kabupaten Barru. ${ }^{6}$

\section{BAHAN DAN METODE}

Penelitian ini adalah survey analitik dengan pendekatan Cross Sectional Study. Populasi dalam penelitian ini adalah seluruh masyarakat yang berumur 21-(>60) tahun dan bertempat tinggal di Desa Lawallu sebanyak 1190 orang. Pengambilan sampel menggunakan metode sistematic random sampling. Variabel independen dalam penelitian ini adalah status gizi sedangkan variabel dependennya adalah pekerjaan dan kondisi sosial. Instrument penelitian yang digunakan adalah kuesioner, timbangan, dan mikrotoise. Kuesioner digunakan untuk analisis data yang berisi daftar pertanyaan yang akan diajukan kepada responden dan sudah tersususn dengan baik yang berisikan daftar pertanyaan kepada responden tentang pekerjaan dan kondisi sosial budaya.
Sedangkan timbangan dan mikrotoise digunakan untuk mengukur indeks massa tubuh (IMT) responden.

HASIL

Hasil penelitian pada Tabel 1 menunjukkan bahwa dari 92 responden yang terbanyak terdapat pada kelompok umur 31-40 tahun yang lebih dari $26.1 \%$ (24 responden), sedangkan klasifikasi terkecil terdapat pada kelompok umur 51-60 tahun yaitu sekitar 13.9\% (13 responden). Untuk sebaran responden berdasarkan jenis kelamin yang terbanyak terdapat pada laki-laki yaitu sebanyak $58.7 \%$ (54 responden), sedangkan pada perempuan yaitu sekitar $41.3 \% \quad$ (38 responden). Berdasarkan pendidikan terakhir responden yang terbanyak terdapat pada tingkat pendidikan tamat SMA/Sederajat, yaitu sebayak 29.3(27 responden), sedangkan klasifikasi terkecil terdapat pada tingkat pendidikan tidak sekolah yaitu $3.3 \%$ (3 responden). Dan responden berdasarkan pekekerjaan kepala keluarga yang terbanyak terdapat pada pekerjaan Nelayan yaitu sebanyak $33.7 \%$ (31 responden), sedangkan klasifikasi terkecil pekerjaan kepala keluarga yaitu PNS, Pegawai Honor, dan Pedagang yaitu $6.5 \%$ (6 responden).

Hasil penelitian pada Tabel 2 menunjukkan bahwa dari 92 , jumlah responden berdasarkan jumlah pendapatan dengan kategori tinggi sebanyak 9.8\% (9 responden), sedang $70.7 \%$ (65 responden), dan 
kategori rendah sekitar 19.5\% (18 responden). Jumlah responden berdasarkan suku (Tabel 3), terbesar ada pada suku Bugis yaitu 93.5\% (86 responden) suku suami dan $97.8 \% \quad$ (90 responden) suku istri, sedangkan suku Makassar, Jawa, dan Mandar masing-masing memiliki jumlah yang sama yaitu $2.2 \%$ (2 responden) per masing-masing suku.

Hasil penelitian pada Tabel 4 menunjukkan bahwa dari 92 ,responden berdasarkan frekuensi makan, yaitu dimana frekuensi makanan 2-3 kali sehari sebanding dengan frekuensi makanan 3 kali sehari yaitu 46 responden.

Hasil penelitian pada Tabel 5 menunjukkan bahwa dari 92 , jumlah responden pada status gizi normal paling tinggi yang berhubungan dengan pekejaan kepala keluarga yaitu pada pekerjaan nelayan sebayak 23 responden (74.2\%). Responden pada status gizi kurus sebanyak 3 responden atau $(9.7 \%)$ pada pekerjaan kepala keluarga nelayan dan responden pada status gizi gemuk tidak memiliki responden di pekerjaan kepala keluarga.

Hasil penelitian pada Tabel 6 menunjukkan bahwa dari 92 , jumlah responden pada status gizi normal paling tinggi yang berhubungan dengan pendapatan yaitu pada pendapatan menengah sebanyak 46 responden (70.8\%). Responden pada status gizi kurus sebanyak 4 responden (6.2\%) yang memiliki tingkat pendapatan menengah dan responden pada status gizi gemuk tidak memiliki responden di tingkat pendapatan rendah. Sedangkan jumlah responden pada status gizi normal paling tinggi yang berhubungan dengan sosial budaya yaitu pada sosial budaya sedang sebanyak 39 responden (81.3\%). Responden pada status gizi kurus sebanyak 3 responden (6.8\%) pada sosial budaya tinggi dan responden pada status gizi gemuk tidak memiliki responden pada sosial budaya rendah (Tabel 7).

\section{PEMBAHASAN}

Berdasarkan hasil Uji Chi Square antara pekerjaaan dengan status gizi menunjukkan hasil yang signifikan $a>0.05$, yaitu $a=0.089$ yang berarti tidak ada hubungan antara pekerjaan terhadap statsu gizi masyarakat di Desa Lawallu.

Status gizi adalah ukuran keberhasilan dalam pemenuhan nutrisi untuk anak yang diindikasikan oleh berat badan dan tinggi badan anak. Status gizi juga didefenisikan sebagai status kesehatan yang dihasilakan ileh keseimbangan antara kebutuhan dan masukan nutrient. Penelitian status gizi merupakan pengukuran yang didasrkan pada data antropometri serta biokimia dan riwayat diit.

Pekerjaan merupakan suatu usaha yang dilakukan seseorang untuk menafkahi kebutuhan sehari-hari, yang kemudian dikaitkan dengan pendapatan perbulan. Pekerjaan seseorang bisa mmpengaruhi status gizinya. Misalnya semakin tinggi mobilitas seseorang dalam bekerja, biasanya semakin 
tinggi pula ketergantungan akan makanan instan yang mana hal ini dapat menganggu asupan nutrisi ke dalam tubuh.

Hasil penelitian menunjukkan bahwa responden dengan tingkat pekerjaan yang dihubungkan dengan ststus gizi rata-rat memiliki status gizi normal, dilihat dari berbagai jenis pekerjaan yang dikerjakan. Keluarga Nelayan misalnya yang dulunya masih banyak yang beranggapan bahwa makan banyak ikan itu dapat menyebabkan cacingan, tetapi seiring perkembangan zaman dan teknologi mereka sudah dapat mengetahui berbagai kandungan gizi yang ada pada ikan sehingga hampir setiap harinya mengkonsumsi berbagai jenis ikan. begitupula dengan berbagai jenis pekerjaan lainnya yang sudah mengetahui jenis makanan yang layak dikonsumsi bukan hanya jenis pekerjaan PNS saja tetapi Buruh juga rata-rata memiliki status gizi normal.

Hasil Uji Chi Square antara pendapatan (pekerjaan) dengan status gizi menunjukkan hasil yang signifikan $a>0.05$, yaitu $p=0.220$ yang berarti tidak ada hubungan antara pendapatan terhadap status gizi masyarakat di Desa Lawallu.

Pendapatan juga dihubungkan dengan pekerjaan terhadap status gizi masyarakat, dulunya semakin tinggi pendapatan seseorang maka semakin bagus pula status gizinya, pada penelitian ini penulis mengaitkan pendapatan dengan ststus gizi masyarakat, sekarang dilihat dari tingkat pendapatan rata-rata masyarakat dengan pendapatan menengah itu memiliki status gizi normal, itu berarti bukan hanya tingkat pendapatan yang tinggi yang bisa memiliki status gizi normal.

Hasil Uji Chi Square antara kondisi sosial budaya dengan status gizi menujukkan hasil yang signifikan $a>0.05$, yaitu $a=0.479$ yang berarti tidak ada hubungan antara kondisi sosial budaya terhadap status gizi masyarakat di Desa Lawallu.

Sosial budaya adalah segala hal yang dicipta oleh manusia dengan pemikiran dan budi nuraninya untuk dan/atau dalam kehidupan bermasyarakat atau lebih singkatnya manuusia membuat sesuatu berdasar budi dan pikirannya yang diperuntukkan dalam kehidupan bermasyarakat

Hasil penelitian menunjukkan bahwa responden dengan tingkat sosial budaya tinggi atau sedang rata-rata memiliki status gizi normal, dilihat dari tingkat kebiasaan makan, penyajian makanan, sampai pengambilan makanan para keluarga yang berbeda-beda bahkan masih ada yang mengikuti adat istiaadat dan kebiasaan turun temurun. Masing-masing suku memiliki perbedaan kebiasaan makan hingga pengambilan makanan, misalnya pada suku Jawa dan Mandar, dimana suku Jawa masih memperhatikan etika pada saat makan yaitu tidak tidak boleh berbicara pada saat makan, dan ketika makan selalu menggunakan sendok, seiring berjalan waktu mereka 
mengikuti kebiasaan makan orang Bugis yang menggunakan tangan ketika maka, begitupun dengan suku Mandar dimana pada saat makan mereka menggunakan cuci tangan (gobokan)/ satu orang, tetapi saat mereka tinggal dan menetap di daerah suku Bugis merekanikut pada cara makan suku Bugis.

Dari penelitian yang dilakukan dapat dilihat bahwa pola makan dan frekuensi makan dalam masyarakat sangat tergantung pada tingkat pendapatannya. Karena tingkat pendapatan yang pas-pasan, jadi para ibu tidak mengutamakan asupan gizi dalam konsumsi dan frekuensi makanan keluarga, menu masakan yang dihidangkan ibu hanya menu makananyang seadanya. Padahal pola asupan gizi yang baik sangat penting bagi anggota keluarga karena gizi berperan penting dalam proses tumbuh kembang pada balita dan akan berpengaruh pada kehidupan anak. Selain itu pola konsumsi pada keluarga sangat dipengaruhi oleh kebudayaan terlihat masih adanya pantangan-pantangan makanan pada anaka yang menjadi kepercayaan ibu dalam menentukan asupan makanan, meski tidak semuanya ibu mempercayai pantangan tersebut.

\section{KESIMPULAN DAN SARAN}

Berdasarkan hasil penelitian dan pembahasan yang dilakukan di Desa Lawallu Kecamatan Soppeng Riaja Kabupaten Barru disimpulkan bahwa tidak ada hubungan pekerjaan dan kondisi sosial budaya dengan status gizi masyarakat di Desa Lawallu. Penelitian ini menyarankan kepada pihak pemerintah diharapkan untuk lebih memperhatikan status gizi masyarakat sehingga dapat dilakukan upaya dalam perbaikan status gizi masyarakat di Desa Lawallu, kepada pihak puskesmas diharapkan memberikan penyuluhan kesehatan terkait masalah-masalah penimgkatan status gizi, kepada masyarakat Lawallu diharapkan agar lebih memperhatikan status gizinya.

\section{DAFTAR PUSTAKA}

1. Departement Kesehatan R.I Analisis Situasi Gizi dan Kesehatan Masyarakat. 2004.[Serial online] Diunduh dari : http://www.depkes.go.id [Diakses pada tanggal 15 Mei 2018].

2. Suhardjo. Perencanaan Pangan dan Gizi. Jakarta: PT Bumi Aksara; 2003.

3. Almatsier, S. Prinsip Dasar Ilmu Gizi. Jakarta: PT Gramedia Pustaka Utama; 2002.

4. Widagdho, Djoko, dkk, Ilmu Budaya Dasar. Jakarta: Bumi Aksara; 2003.

5. Pemerintah Kabupaten Barru. Profil Desa Lawallu Kecamatan Soppeng Riaja Kabupaten Barru tahun 2017. Barru; 2018.

6. Beck, M. Ilmu Gizi dan Diet. (terj.). Yayasan Essentia Medica : Yogjakarta; 2000.

7. Ali Khomsan. Sosiobudaya Pangan Suku Baduy. Jurnal "Gizi dan Pangan", 
Departemen Gizi Masyarakat, Fakultas

Ekologi Manusia, Institut Pertanian

Bogor Indonesia; 2009.

8. Notoadmodjo,S.Metode Penelitian

Kesehatan. Jakarta: Rineka Cipta; 2012

9. Sasha. Pengertian Sosial Budaya : Makna

Sistem dan Contohnya. Jakarta artikelaz.com; 2016.

10. Kottler dan Keller. Faktor Budaya Sebagai Faktor Penentu Jakarta; 2009.

11. Waryono. Health Education. Artikel Karya Ilmiah; 2010.
12. Suhardjo. Perencanaan Pangan dan Gizi. Jakarta: PT Bumi Aksara; 2006.

13. Supariasa. I.D.NPenilaian Status Gizi: Buku Kedokteran EGC. Jakarta; . 2009.

14. Rusliani. Kepercayaan. Jakarta; 2004.

15. Meiyenti dan Nurti. Makanan dan Gizi dalam Konteks Sosial Budaya. Jurnal Antropologi Universitas Andalas, 2004;5(7):33-45.

16. Notoadmodjo,S. Metode Penelitian Kesehatan. Jakarta: Rineka Cipta; 2012.

\section{LAMPIRAN}


Tabel 1. Distribusi Karakteristik Responden Berdasarkan Umur, Jenis Kelamin di Desa Lawallu Kecamatan Soppeng Riaja Kabupaten Barru

\begin{tabular}{lcc}
\hline \multicolumn{1}{c}{ Karakteristik } & Frekuensi (f) & Persentase (\%) \\
\hline Umur & 22 & 23 \\
$21-30$ & 24 & 26.1 \\
$31-40$ & 16 & 17.5 \\
$41-50$ & 13 & 13.9 \\
$51-60$ & 17 & 19.5 \\
$>60$ & $\mathbf{9 2}$ & $\mathbf{1 0 0 . 0}$ \\
\hline Total & & \\
Jenis Kelamin & 54 & 58.7 \\
Laki-laki & 38 & 41.3 \\
Perempuan & $\mathbf{9 2}$ & $\mathbf{1 0 0 . 0}$ \\
\hline Total & & \\
\hline Pendidikan Terakhir & 3 & 3.3 \\
Tidak Sekolah & 25 & 27.2 \\
Tamat SD & 25 & 27.2 \\
Tamat SMP/sederajat & 27 & 29.3 \\
Tamat SMA/sederajat & 12 & 13 \\
Tamat Akademi/PT & $\mathbf{9 2}$ & $\mathbf{1 0 0 . 0}$ \\
\hline Total & & 6.5 \\
\hline Pekerjaan Kepala Keluarga & 6 & 6.5 \\
PNS/Pensiunan PNS & 6 & 18.5 \\
Pegawai Honor & 17 & 33.7 \\
Petani & 31 & 6.5 \\
Nelayan & 6 & 8.7 \\
Pedagang & 8 & 19.6 \\
Buruh & 18 & $\mathbf{1 0 0 . 0}$ \\
Wiraswasta & $\mathbf{9 2}$ &
\end{tabular}

Tabel 2. Distribusi Responden Berdasarkan Pendapatan Kepala Keluarga di Desa Lawallu Kecamatan Soppeng Riaja Kabupaten Barru

\begin{tabular}{lcc}
\hline \multicolumn{1}{c}{ Pendapatan } & Frekuensi (f) & Persentase (\%) \\
\hline Tinggi & 9 & 9.8 \\
Menengah & 65 & 70.7 \\
Rendah & 18 & 19.5 \\
\hline Total & $\mathbf{9 2}$ & $\mathbf{1 0 0 . 0}$ \\
\hline
\end{tabular}


Tabel 3. Distribusi Responden Berdasarkan Suku di Desa Lawallu Kecamatan Soppeng Riaja

\begin{tabular}{llclc}
\multicolumn{5}{c}{ Kabupaten Barru } \\
\hline Suku & Suku Suami & \multicolumn{2}{c}{ Suku Istri } \\
& f & \% & f & \% \\
\hline Bugis & 86 & 93.5 & 90 & 97.8 \\
Makassar & 2 & 2.2 & 2 & 2.2 \\
Jawa & 2 & 2.2 & 0 & 0 \\
Mandar & 2 & 2.2 & 0 & 0 \\
\hline Total & $\mathbf{9 2}$ & $\mathbf{1 0 0 . 0}$ & $\mathbf{9 2}$ & $\mathbf{1 0 0 . 0}$ \\
\hline
\end{tabular}

Tabel 4. Distribusi Responden Berdasarkan Frekuensi Makan di Desa Lawallu Kecamatan Soppeng Riaja Kabupaten Barru

\begin{tabular}{lcc}
\hline \multicolumn{1}{c}{ Frekuensi Makan } & Frekuensi (f) & Persentase (\%) \\
\hline Makan 1-2 kali sehari & 0 & 0 \\
Makan 2-3 kali sehari & 46 & 50 \\
Makan 3 kali sehari & 46 & 50 \\
\hline Total & $\mathbf{9 2}$ & $\mathbf{1 0 0 . 0}$ \\
\hline
\end{tabular}

Tabel 5. Hubungan Pekerjaan dan Status Gizi di Desa Lawallu Kecamatan Soppeng Riaja Kabupaten

\begin{tabular}{|c|c|c|c|c|c|c|c|c|c|}
\hline \multicolumn{10}{|c|}{ Barru } \\
\hline \multirow{3}{*}{$\begin{array}{c}\text { Pekerjaan Kepala } \\
\text { Keluarga }\end{array}$} & \multicolumn{9}{|c|}{ Status Gizi } \\
\hline & \multicolumn{2}{|c|}{ Kurus } & \multicolumn{2}{|c|}{ Normal } & \multicolumn{2}{|c|}{ Gemuk } & \multicolumn{2}{|c|}{ Total } & \multirow[t]{2}{*}{$P$} \\
\hline & $\mathrm{n}$ & $\%$ & $\mathrm{n}$ & $\%$ & $\mathrm{n}$ & $\%$ & $\mathrm{n}$ & $\%$ & \\
\hline PNS/Pensiunan PNS & 0 & 0 & 5 & 83.3 & 1 & 16.7 & 6 & 100.0 & \\
\hline Pegawai Honor & 1 & 16.7 & 4 & 66.6 & 1 & 16.7 & 6 & 100.0 & \\
\hline Petani & 0 & 0 & 16 & 94.1 & 1 & 5.9 & 17 & 100.0 & \\
\hline Nelayan & 3 & 9.7 & 23 & 74.2 & 5 & 16.1 & 31 & 100.0 & 0.089 \\
\hline Pedagang & 0 & 0 & 2 & 33.3 & 4 & 66.7 & 6 & 100.0 & \\
\hline Buruh & 0 & 0 & 8 & 100 & 0 & 0 & 8 & 100.0 & \\
\hline Wiraswata & 1 & 5.6 & 12 & 66.6 & 5 & 27.8 & 18 & 100.0 & \\
\hline Total & 5 & 5.4 & 70 & 76.1 & 17 & 18.5 & 92 & 100.0 & \\
\hline
\end{tabular}

Tabel 6. Hubungan Pendapatan (pekerjaan) dan Status Gizi di Desa Lawallu Kecamatan Soppeng Riaja Kabupaten Barru

\begin{tabular}{|c|c|c|c|c|c|c|c|c|c|}
\hline \multirow{3}{*}{ Pendapatan } & \multicolumn{9}{|c|}{ Status Gizi } \\
\hline & \multicolumn{2}{|c|}{ Kurus } & \multicolumn{2}{|c|}{ Normal } & \multicolumn{2}{|c|}{ Gemuk } & \multicolumn{2}{|c|}{ Total } & \multirow[t]{2}{*}{$P$} \\
\hline & $\mathrm{n}$ & $\%$ & $\mathrm{n}$ & $\%$ & $\mathrm{n}$ & $\%$ & $\mathrm{n}$ & $\%$ & \\
\hline Tinggi & 0 & 0 & 7 & 77.8 & 2 & 22.2 & 9 & 100.0 & \\
\hline Menengah & 4 & 6.2 & 46 & 70.8 & 15 & 23.1 & 65 & 100.0 & 0.220 \\
\hline Rendah & 1 & 5.6 & 17 & 94.4 & 0 & 0 & 18 & 100.0 & \\
\hline Total & 5 & 5.4 & 70 & 76.1 & 17 & 18.5 & 92 & 100.0 & \\
\hline
\end{tabular}


Tabel 7. Hubungan Sosial Budaya dan Status Gizi di Desa Lawallu Kecamatan Soppeng Riaja Kabupaten Barru

\begin{tabular}{|c|c|c|c|c|c|c|c|c|c|}
\hline \multirow{3}{*}{ Sosial Budaya } & \multicolumn{9}{|c|}{ Status Gizi } \\
\hline & \multicolumn{2}{|c|}{ Kurus } & \multicolumn{2}{|c|}{ Normal } & \multicolumn{2}{|c|}{ Gemuk } & \multicolumn{2}{|c|}{ Total } & \multirow[t]{2}{*}{$P$} \\
\hline & $\mathrm{n}$ & $\%$ & $\mathrm{n}$ & $\%$ & $\mathrm{n}$ & $\%$ & $\mathrm{n}$ & $\%$ & \\
\hline Tinggi & 3 & 6.8 & 31 & 70.5 & 10 & 22.7 & 44 & 100.0 & \\
\hline Sedang & 2 & 4.2 & 39 & 81.3 & 7 & 14.6 & 48 & 100.0 & 0.479 \\
\hline Rendah & 0 & 0 & 0 & 0 & 0 & 0 & 0 & 100.0 & \\
\hline Total & 5 & 5.4 & 70 & 76.1 & 17 & 18.5 & 92 & 100.0 & \\
\hline
\end{tabular}

